\title{
PEMODELAN DAN PENERAPAN METODE RFM PADA ESTIMASI NILAI KONSUMEN (CUSTOMER LIFETIME VALUE) MENGGUNAKAN K-MEANS CLUSTERING MACHINE LEARNING
}

(Modeling and Application of the RFM Method on the Estimation of Customer Lifetime Value Using K-Means Clustering Machine Learning)

\section{Bagaskoro Cahyo Laksono', Ika Yuni Wulansari²}

\author{
1,2Politeknik Statistika STIS \\ 1,2]alan Otto Iskandardinata No. 64C 14, Rt.1/Rw.4, Bidara Cina, Jatinegara, Jakarta Timur 13330
}

\section{1@stis.ac.id}

\begin{abstract}
ABSTRAK
Krisis Covid-19 berdampak pada revenue perusahaan, jika perusahaan tidak meningkatkan strategi pemasaran yang tepat terhadap konsumen, akan beresiko gulung tikar karena tidak memiliki target pasar yang jelas. Disamping itu, perusahaan dapat mengembangkan bisnisnya menggunakan big data untuk mendukung decision making. Big data dalam industry e-commerce yang mencakup ukuran dan kecepatan transaksi yang tinggi dapat digunakan untuk menganalisis perilaku konsumen bahkan memprediksi nilai konsumen. Pada zaman sekarang perusahaan mulai mengembangkan ketertarikan bisnis yang berorientasi konsumen daripada berorientasi produk. Salah satu cara yang dapat digunakan untuk menentukan nilai konsumen yaitu dengan menghitung Customer Lifetime Value (CLV). Dengan mengetahui CLV di level individu, akan berguna untuk membantu pengambil keputusan untuk mengembangkan segmentasi konsumen dan alokasi sumber daya. Penting dilakukan segmentasi atau pengelompokkan konsumen yang menggambarkan kelompok loyalitas konsumen. Oleh karena itu tujuan dalam penelitian ini adalah melakukan penghitungan $C L V$ dan segmentasi konsumen dengan menggunakan metode analisis RFM dengan K-Means Clustering Machine Learning Model. Tahapan analisis diantaranya mendefinisikan RFM Segmentation Value yang merupakan clustering yang dibangun dari angka kumulatif yang berisi penjumlahan Recency, Frequency dan Monetary Level yang dimiliki masing-masing konsumen. Kombinasi nilai leve/ yang tercipta berkisar antara $0,1,2,3,4,5,6$ yang artinya semakin tinggi nilainya maka semakin berharga konsumen tersebut. Pada akhirnya, metode segmentasi konsumen yang di bangun penulis dapat digunakan untuk optimasi strategi perusahaan untuk mendapat profit yang maksimum. Metode ini dapat diterapkan pada berbagai kasus dan perusahaan lain. Hasil penelitian ini diharapkan dapat membantu perusahaan untuk bertahan di tengah krisis akibat Covid-19.
\end{abstract}

Kata kunci: segmentasi konsumen, analisis RFM, K-Means Clustering, CLV

\section{ABSTRACT}

The Covid-19 crisis has an impact on company revenue, if the company does not improve the right marketing strategy for consumers, it will risk going out of business because it does not have a clear target market. In addition, companies can develop their business using big data to support decision making. Big data in the e-commerce industry which includes high transaction sizes and speeds can be used to analyze consumer behavior and even predict consumer value. Nowadays companies are starting to develop business interests that are consumer oriented rather than product oriented. One way that can be used to determine consumer value is by calculating the Customer Lifetime Value (CLV). Knowing CLV at the individual level will be useful for helping decision makers to develop consumer segmentation and resource allocation. Hence, it is important to do segmentation or consumer grouping that describes consumer loyalty groups. Therefore, the purpose of this study is to calculate CLV and consumer segmentation using the RFM analysis method with the K-Means Clustering Machine Learning Model. The analysis stages include defining the RFM Segmentation Value, which is a clustering built from a cumulative number that contains the sum of the Recency, Frequency and Monetary Level of each consumer. So that the combination of level values created ranges from $0.1,2,3,4,5,6$, which means that the higher the value, the more valuable the consumer is. In the 
end, the consumer segmentation method that was built by the author can be used to optimize the company's strategy to get maximum profit. This method can be applied to various cases and other companies. The results of this study are expected to help companies survive the crisis caused by Covid-19

Keywords: customer segmentation, RFM analysis, K-Means Clustering

\section{PENDAHULUAN}

1. Latar Belakang

Covid-19 telah berdampak besar terhadap pola marketing barang dan jasa. Peraturan untuk tinggal di rumah (stay at home) menyebabkan perubahan radikal dalam permintaan untuk kategori produk tertentu, saluran distribusi berkurang, kesulitan rantai pasokan yang telah mengganggu perilaku kebiasaan konsumen dan mengharuskan pelanggan untuk berbelanja dengan cara baru. Keadaan saat ini menawarkan sesuatu yang belum pernah terjadi sebelumnya. Hal ini membuka peluang bagi perusahaan untuk bersaing terutama dalam hal pangsa pasar dan target konsumen yang potensial.

Di samping itu, saat ini adalah era revolusi informasi, masalah pemasaran baru bermunculan yang memerlukan penelitian mendalam. Permasalahan baru yang muncul ini menarik untuk diselidiki sehingga masalah lama dapat dianalisis dengan cara yang lebih baik karena ketersediaan data yang lebih baik. Dalam riset pemasaran, analisis Customer Lifetime Value (CLV) adalah salah satu metode baru dalam perkembangan bidang pemasaran untuk menentukan kelompok konsumen yang potensial.

Menurut Gupta (2006), saat ekonomi modern menjadi berbasis layanan, perusahaan semakin memperoleh pendapatan dari penciptaan dan pemeliharaan hubungan jangka panjang dengan pelanggan/ konsumen. Dalam lingkungan seperti itu, pemasaran bertujuan untuk memaksimalkan Customer Lifetime Value (CLV) dan ekuitas konsumen, yang merupakan jumlah nilai konsumen perusahaan.

Nilai konsumen memainkan peran penting di jantung semua aktivitas pemasaran sehingga mendapat perhatian dari setiap peneliti konsumen (Holbrook, 1999). CLV adalah nilai sekarang dari ekspektasi keuntungan atau kerugian yang akan diperoleh perusahaan selama melakukan transaksi dengan konsumen. Menurut Khajvand (2011) pada pendekatan berdasarkan customercentric, konsumen dianggap sebagai suatu aset. Keuntungan yang didapat oleh suatu perusahaan tidak hanya dipengaruhi oleh lama dan banyaknya konsumen, tetapi juga dari kualitas konsumen tersebut (Reinartz dan Kumar, 2000). Pendekatan ini yang dianggap paling baik, sehingga terjadi perubahan paradigma dalam pengambilan keputusan bisnis suatu perusahaan. Tentunya untuk mendapatkan nilai CLV membutuhkan data yang mendukung. Sehingga, saat ini beberapa perusahaan seperti telekomunikasi, retailers, perbankan dan masih banyak lagi menghimpun informasi konsumen dan data transaksi untuk mengidentifikasikan kebiasaan konsumen untuk jangka waktu tertentu (Ma et al., 2011). Mengetahui CLV di level individu akan berguna untuk membantu pengambil keputusan untuk mengembangkan segmentasi konsumen dan alokasi sumber daya (Kumar et al., 2006; Kim and Lee, 2007).

Salah satu cara untuk mengatur hubungan perusahaan dengan konsumennya adalah melalui siklus kehidupan konsumen (Customer Life Cycle), yang terdiri dari konsumen akuisisi, konsumen retensi, dan pengembangan konsumen, ( $F$. Buttle, 2009). Pada tahap konsumen akuisisi perusahaan harus memilih beberapa konsumen yang memiliki potensi baik. Selanjutnya, masuk pada tahap konsumen retensi yaitu perusahaan berusaha menjaga konsumen yang memiliki nilai tinggi agar tidak diakuisisi oleh perusahaan lain. Tahap berakhir merupakan pengembangan konsumen, yaitu proses pengembangan yang dilakukan perusahaan sehingga diharapkan konsumen akan memberikan keuntungan lebih untuk perusahaan.

Namun tidak mudah untuk mengetahui bagaimana cara perusahaan menentukan konsumen yang baik untuk diakuisisi, diretensi dan dikembangkan. Karena setiap tahap dari siklus kehidupan konsumen membutuhkan biaya dan sumber daya yang tidak sedikit. Maka dari itu pemahaman terhadap Customer Lifetime Value (CLV) menjadi sangat penting, karena CLV memberikan suatu 
ukuran yang jelas yaitu berupa nilai sekarang dari ekspektasi keuntungan atau kerugian yang akan diperoleh perusahaan selama melakukan transaksi dengan konsumen (Berger dan Nashr, 1998).

Oleh karena itu dalam penelitian ini akan dihitung Customer Lifetime Value dan segmentasi konsumen dengan menggunakan metode analisis RFM dengan K-Means Machine Learning Model.

\section{Rumusan masalah}

Berdasarkan latar belakang di atas, dirumuskan permasalahan penelitian sebagai berikut:

a. Bagaimana mengestimasi nilai CLV seorang konsumen perusahaan

b. Bagaimana membuat segmentasi konsumen

\section{Tujuan}

Berdasarkan latar belakang dan perumusan masalah di atas, tujuan dalam penelitian ini adalah:

a. Mengestimasi nilai CLV berdasarkan recency, frequency dan monetary/revenue yang dihasilkan konsumen

b. Melakukan segmentasi konsumen menggunakan analisis RFM dengan machine learning

4. Manfaat

Kegunaan atau manfaat dari penelitian ini adalah:

a. Menghasilkan keputusan yang lebih baik dan tepat dalam hal penggunaan sumber daya yang tersedia.

b. Perusahaan dapat menentukan strategi akuisisi, retensi dan pengembangan konsumen yang tepat

c. Perusahaan dapat menentukan strategi untuk meningkatkan CLV konsumen

\section{METODE}

1. Metode Analisis

Penelitan ini menggunakan metode analisis RFM dan K-Means Clustering Machine Learning untuk menentukan estimasi nilai konsumen dan mensegmentasi konsumen.

\subsection{Analisis RFM (Recency, Frequency dan Monetary Value)}

RFM merupakan metode analisis yang digunakan untuk membuat segmentasi konsumen menjadi beberapa kelas tertentu. Dalam penelitian ini akan dibagi menjadi 3 jenis yaitu low, middle dan high value. Analisis RFM sangat bergantung pada data transaksi yang dilakukan oleh konsumen.

a. Recency atau keterkinian: mengindikasikan pelanggan telah membeli sesuatu baru-baru ini. Pelanggan yang membeli belum lama ini lebih cenderung bereaksi terhadap penawaran baru daripada pelanggan yang transaksi pembeliannya sudah terjadi sejak lama.

b. Frequency atau frekuensi: memperlihatkan banyaknya pembelian yang dilakukan konsumen. Jika pelanggan melakukan pembelian lebih sering, hal itu akan menghasilkan respon lebih positif lebih tinggi daripada pelanggan yang jarang membeli sesuatu.

c. Monetary Value atau nilai uang: omset pembelian atau nilai moneter mengacu pada semua pembelian yang dilakukan oleh pelanggan. Pelanggan yang menghabiskan lebih banyak uang untuk pembelian lebih cenderung menanggapi penawaran daripada pelanggan yang telah menghasilkan jumlah yang lebih kecil.

Skor RFM merupakan hasil dari pembobotan sedemikian rupa dari ketiga komponen tersebut. Skor RFM dapat membantu mengidentifikasi pelanggan dengan daya beli terbesar dan dapat diklasifikasikan kedalam kelompok tertentu.

\subsection{K-Means Clustering}

K-Means merupakan unsupervised machine learning algorithms yang bertujuan untuk menemukan grup dalam data, dengan jumlah grup/kelompok yang diwakili oleh variabel $\mathrm{K}$. 
Variabel $\mathrm{K}$ sendiri adalah jumlah cluster yang dinginkan. Untuk memproses data algoritma $K$ means Clustering, data dimulai dengan kelompok pertama centroid yang dipilih secara acak, yang digunakan sebagai titik awal untuk setiap cluster, dan kemudian melakukan perhitungan berulang untuk mengoptimalkan posisi centroid. Proses akan berhenti ketika:

a. Centroid telah stabil

b. Jumlah iterasi yang ditentukan telah tercapai

Proses pengelompokan data kedalam suatu cluster dapat dilakukan dengan cara menghitung jarak terdekat dari sebuah data ke sebuah titik centroid. Perhitungan jarak Minkowski dapat digunakan untuk menghitung jarak antar dua buah data. rumus untuk menghitung jarak tersebut adalah

$$
d\left(x_{i}, x_{j}\right)=\left(\left|x_{i 1}-x_{j 1}\right|^{g}+\left|x_{i 2}-x_{j 2}\right|^{g}+\cdots+\left|x_{i p}-x_{j p}\right|^{g}\right)^{\frac{1}{g}}
$$

Dimana:

$g=1$, untuk menghitung jarak Manhattan

$g=2$, untuk menghitung jarak Euclidean

$g=\infty$, untuk menghitung jarak Chebychev

$x_{i}, x_{j}$ adalah dua buah data yang akan dihitung jaraknya

$p=$ dimensi dari sebuah data

Pembaharuan suatu titik centroid dapat dilakukan dengan rumus berikut:

Dimana:

$$
\mu_{k}=\frac{1}{N_{k}} \sum_{q=1}^{N_{k}} x_{q}
$$

$\mu_{k}=$ titik centroid dari cluster ke-K

$N_{k}=$ banyaknya data pada cluster ke-K

$X_{q}=$ data ke-q pada cluster ke-K

2. Alur Penelitian

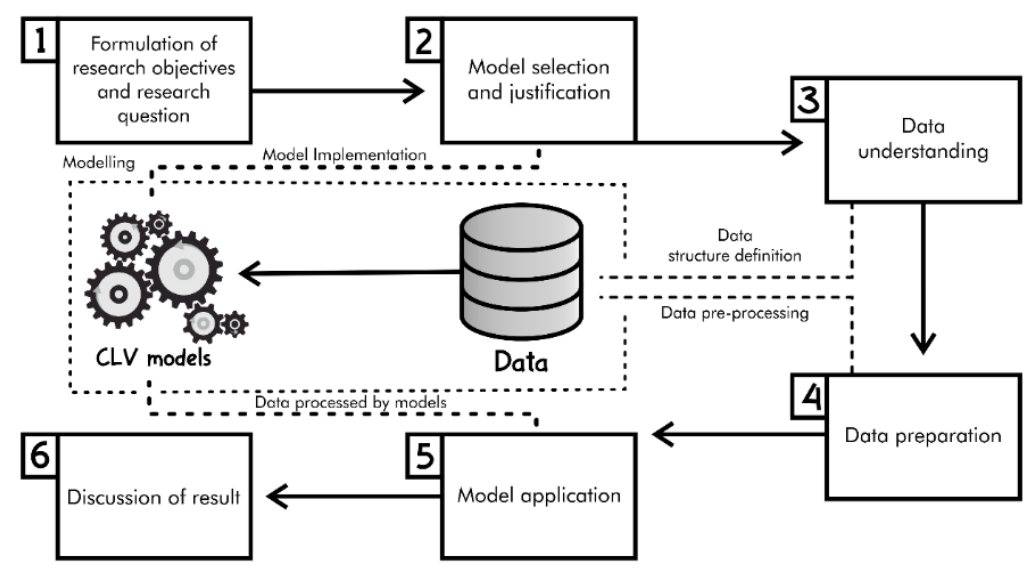

Gambar 59. Alur Penelitian.

3. Pengumpulan Data

Data yang di gunakan merupakan data sekunder online retail yang diperoleh dari Shailaja Gupta di website kaggle.com/shailaja4247. Dataset akan diolah menggunakan software R. 


\section{HASIL DAN PEMBAHASAN}

CLV dapat diartikan sebagai total profit oleh semua hubungan yang diakukan perusahaan dengan pelanggan. Secara umum profit merupakan total revenue dikurangi total cost. CLV menganalisis konsumen secara individu dengan rumus sebagai berikut:

$$
C L V=\text { Total Revenue }- \text { Total Cost }
$$

Dalam penelitian ini, akan di bangun machine learning model untuk menghitung nilai konsumen dan melakukan segmentasi konsumen. Di dalam dataset tidak terdapat variabel cost. Sehingga analisis akan difokuskan untuk menghitung bagian revenue untuk mempresentasikan nilai konsumen.

\section{Analisis RFM}

Salah satu metode untuk mengevaluasi nilai konsumen atau CLV adalah RFM. RFM akan membagi nilai untuk setiap konsumen menjadi tiga komponen yaitu berdasarkan skor perhitungan recency, frequency dan monetary. Berdasarkan dataset yang diperoleh terdapat 541909 transaksi yang terjadi, kemudian dilakukan pengelompokkan berdasarkan konsumen yang unik dalam variabel CustomerID dan diperoleh terdapat 4228 konsumen berbeda. Kemudian dilakukan perhitungan masing-masing komponen yaitu recency, frequency dan recency.

Variabel recency diperoleh dari hasil pengurangan atau selisih dari tanggal terakhir transaksi yang ada didalam dataset dikurangi dengan tanggal terakhir konsumen tertentu melakukan transaksi. Sehingga dapat diinterpretasikan bahwa, semakin tinggi nilai recency maka nilai konsumen akan semakin rendah, karena hal itu merepresentasikan bahwa konsumen jarang atau tidak lagi melakukan transaksi dengan online retail tersebut. Nilai variabel frequency diperoleh dari banyaknya invoiceid yang dilakukan konsumen. Hal itu menandakan semakin tinggi nilai frequency maka konsumen semakin banyak melakukan transaksi dan menunjukkan nilai konsumen yang positif. Variabel monetary dihitung dari banyaknya pemesanan dikali harga barang kemudian dibagi dengan banyaknya transaksi yang dilakukan.

Tabel 45. Hasil Analisis RFM

\begin{tabular}{|r|r|r|r|r|}
\hline No & rustomerID & Recency & Frequency & Monetary \\
\hline 1 & 12346 & 348 & 1 & 77183.6 \\
\hline 2 & 12347 & 25 & 7 & 615.7143 \\
\hline 3 & 12348 & 98 & 4 & 449.31 \\
\hline 4 & 12349 & 41 & 1 & 1757.55 \\
\hline 5 & 12350 & 333 & 1 & 334.4 \\
\hline dst & & & & \\
\hline
\end{tabular}

Set data, olah. Ditampilkan 5 dari 4338 Konsumen

a. Recency

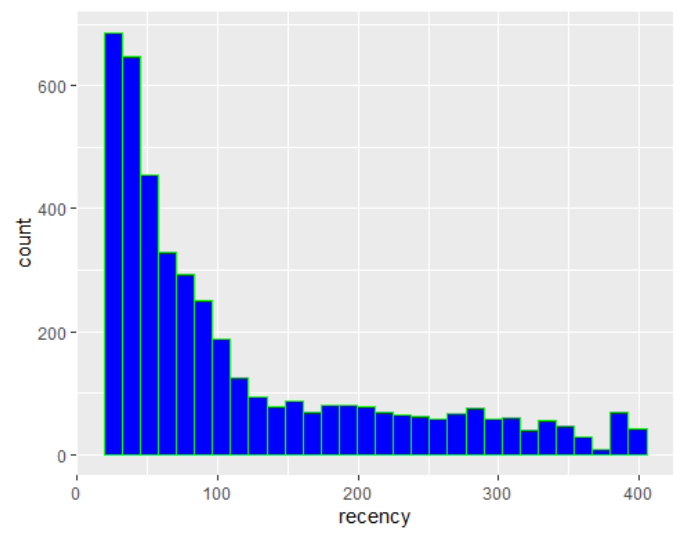

Dari grafik di samping dapat diketahui bahwa nilai recency berdistiribusi menceng kanan dan memiliki nilai minimum 23 dan nilai maksimumnya 396. Dengan nilai rata-rata sebesar 115.1 dan standard deviasi 100.0123 
Gambar 2 Distribusi Recency Konsumen

b. Frequency

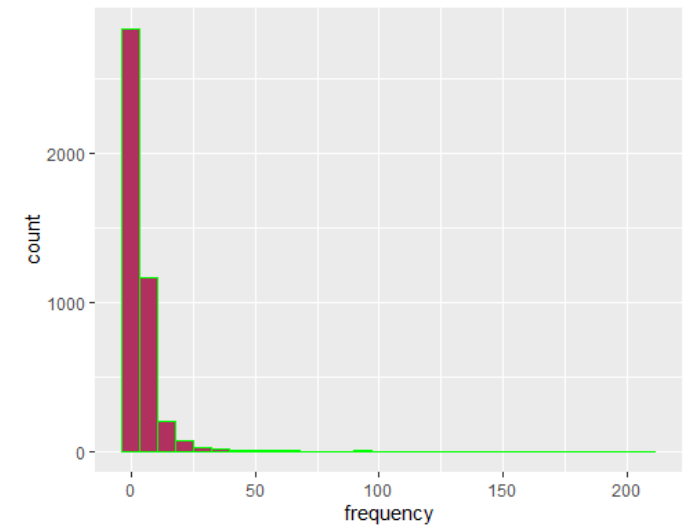

Gambar 3 Distribusi Frequency Konsumen

\section{c. Monetary}

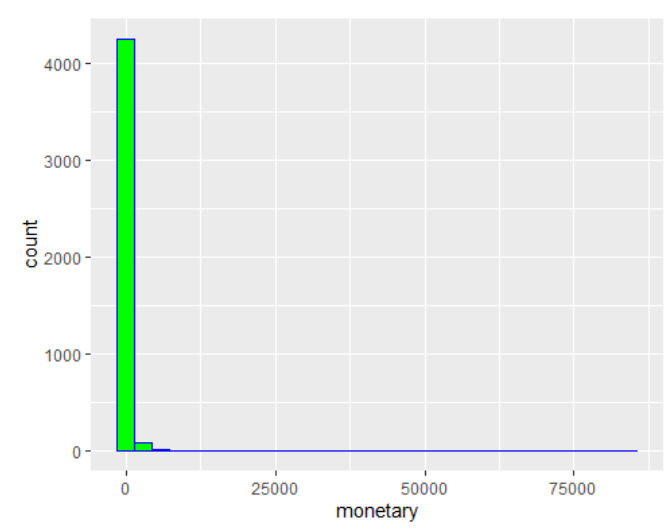

Dari grafik disamping dapat diketahui bahwa nilai frequency berdistribusi menceng kanan dan memiliki nilai minimum 3.45 dan nilai maksimumnya 84236. Dengan nilai rata-rata sebesar 419.17 dan standard deviasi 1795.538

Berdasarkan hasil analisis secara umum dapat ditunjukkan bahwa terdapat 4338 pelanggan pada online retail tersebut memiliki masing-masing nilai RFM. Berdasarkan analisis diperoleh angka recency, frequency dan monetary, angka recency yang semakin besar menunjukan bahwa konsumen sudah lama membeli di toko tersebut, tentunya angka recency yang besar akan memberikan nilai negatif keaktifan pelanggan. Angka frequency menunjukkan banyaknya quantitas pembelian. Dan monetary menunjukkan angka revenue yang diperoleh perusahaan dari konsumen.

\section{Segmentasi Konsumen dengan K-Means Clustering Machine Learning Model}

Perhitungan RFM skor dan melakukan segmentasi konsumen merupakan teknik yang dapat dikembangkan oleh masing-masing perusahaan oleh karena itu mereka memiliki masing-masing metode dan hasilnya kemungkinan berbeda-beda juga sesuai dengan strategi dan kebijakan yang ingin dicapai perusahaan. Dalam penelitian ini penulis berinovasi untuk menentukan segmentasi menggunakan salah satu teknik clustering yaitu K-Means Clustering. Pada subbab sebelumnya telah diperoleh variabel recency, frequency dan monetary yang merupakan representasi dari nilai konsumen. Pada subbab ini akan dilakukan clustering dari masing-masing ketiga variabel tersebut kemudian diakhir akan diakumulasi untuk mendapatkan RFM Segmentation Value. 
Segmentasi untuk masing-masing komponen didefinisikan dan terbagi menjadi 3 leviel kategori yaitu $0={ }^{\text {"Low }}$, $1={ }^{\text {"Middle }}{ }^{\mathrm{N}}$, dan $2={ }^{\text {"High" }}$ value sehingga dapat diketahui diawal bahwa nilai $K=3$. Kemudian akan dilakukan perhitungan masing-masing komponen yaitu recency, frequency dan recency dan didapatkan hasil sebagai berikut:

Tabel 2.Hasil Analisis K-Means Clustering

\begin{tabular}{|c|c|c|c|c|c|c|c|c|c|c|c|}
\hline \multicolumn{4}{|c|}{ Recency } & \multicolumn{4}{|c|}{ Frequency } & \multicolumn{4}{|c|}{ Monetary } \\
\hline $\begin{array}{l}\mathrm{Cl} \\
\text { us } \\
\text { ter }\end{array}$ & Means & Size & Level & $\begin{array}{l}\mathrm{Cl} \\
\text { us } \\
\text { ter }\end{array}$ & Means & Size & Level & $\begin{array}{l}\mathrm{Cl} \\
\text { us } \\
\text { ter }\end{array}$ & Means & Size & Level \\
\hline 1 & 54.85 & 2914 & 2 & 1 & 121.750 & 8 & 2 & 1 & 354.543 & 4308 & 0 \\
\hline 2 & 316.94 & 626 & 0 & 2 & 20.101 & 277 & 1 & 2 & 4626.940 & 28 & 1 \\
\hline 3 & 176.53 & 798 & 1 & 3 & 2.958 & 4053 & 0 & 3 & 80709.925 & 2 & 2 \\
\hline
\end{tabular}

Pemberian value/level masing-masing komponen RFM berbeda berdasarkan karakteristiknya. Pada Clustering Recency value 0 atau Low diberikan pada cluster 2 karena memiliki means terbesar yaitu 316.99441 yang berarti konsumen sudah sangat lama tidak melakukan transaksi. Untuk clustering Frequency dan Monetary pemberian value/level berdasarkan nilai means terendah ke tertinggi, karena semakin besar frequency dan monetary yang dimiliki konsumen menandakan konsumen tersebut memiliki nilai CLV yang tinggi.

Tahapan analisis selanjutnya adalah mendefinisikan RFM Segmentation Value. RFM Segmentation Value merupakan clustering yang dibangun dari angka kumulatif yang berisi penjumlahan Recency Level, Frequency Level dan Monetary Level yang dimiliki masing-masing konsumen. Sehingga kombinasi nilai cluster yang tercipta adalah berkisar antara 0,1,2,3,4,5,6 yang artinya semakin tinggi cluster maka semakin berharga konsumen tersebut. Ketika konsumen terdapat pada RFM Segmentation Value yang tinggi, konsumen tersebut layak untuk dipertahankan oleh perusahaan.

Tabel 3. Hasil Perhitungan RFM Segmentation Value

\begin{tabular}{|r|r|r|r|r|r|r|}
\hline No & CustomerID & $\begin{array}{l}\text { Recency } \\
\text { Level }\end{array}$ & $\begin{array}{l}\text { Frequency } \\
\text { Level }\end{array}$ & $\begin{array}{l}\text { Monetary } \\
\text { Level }\end{array}$ & $\begin{array}{l}\text { RFM } \\
\text { Segmentation } \\
\text { Value }\end{array}$ \\
\hline 1 & 12346 & 0 & 0 & 2 & 2 \\
\hline 2 & 12347 & 2 & 0 & 0 & 2 \\
\hline 3 & 12348 & 2 & 0 & 0 & 2 \\
\hline 4 & 12349 & 2 & 0 & 0 & 2 \\
\hline 5 & 12350 & 0 & 0 & 0 & 0 \\
\hline Dst & & & & & \\
\hline
\end{tabular}

Set data, olah. Ditampilkan 5 dari 4338 Konsumen

Nilai RFM Segmentation Value pada tabel diatas merupakan implementasi hasil perhitungan dari perumusan sebagai berikut:

$$
\text { RFM Segmentation Value }=\text { Recency Level }+ \text { Frequency Level }+ \text { Monetary Level }
$$

Sebagai contoh pada Tabel 3 untuk CustomerID 12346 memiliki Recency level 0, Frequency level 0 dan Monetary level 2. Sehingga berdasarkan perumusan diatas, dapat dihitung bahwa RFM Segmentation Value untuk Customer ID 12346 adalah 2. Begitu juga untuk konsumen berikutnya dengan perhitungan yang sama maka diperoleh semua nilai dalam variabel RFM Segmentation Value. 


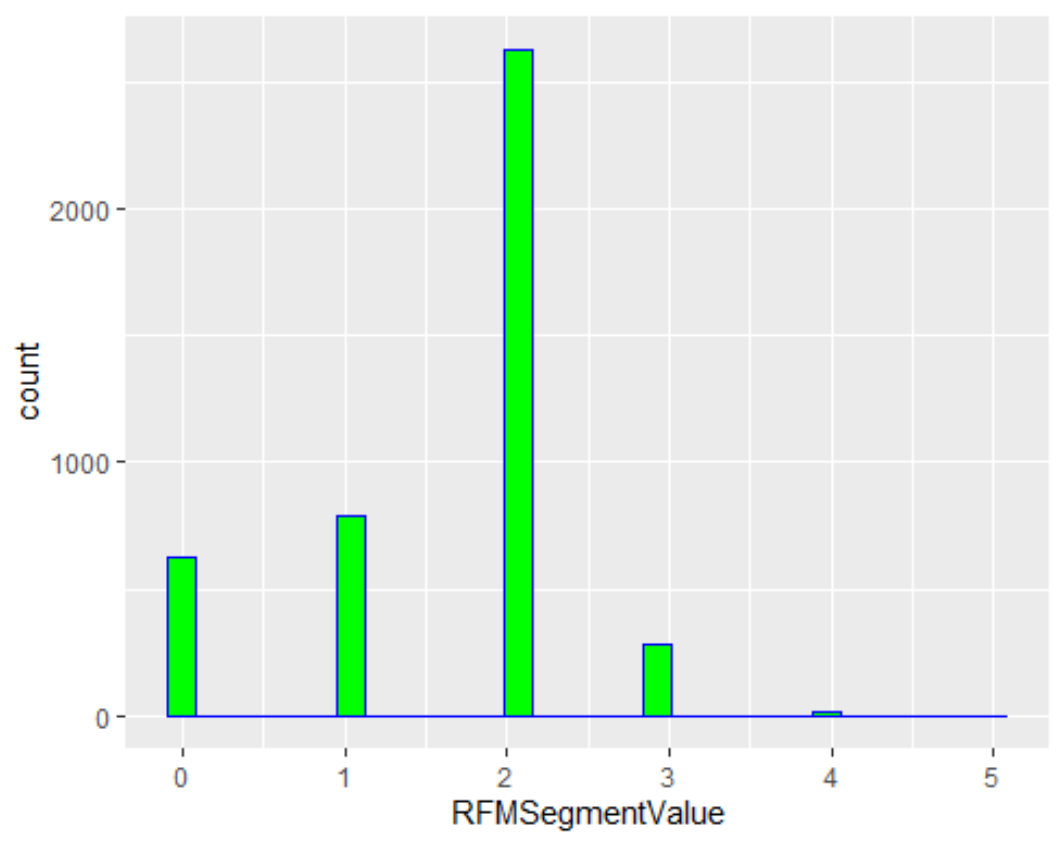

Gambar 5 Distribusi RFM Segmentation Value Konsumen

Grafik diatas menunjukkan persebaran dari nilai RFM Segmentation Value untuk 4338 konsumen. Diperoleh bentuk visualisasi awal bahwa jumlah konsumen dengan RFM Segmentation Value 2 terbanyak dibandingkan yang lain. Berdasarkan hasil pengolahan dataset, dari 4228 konsumen paling banyak terdapat pada RFM Segmentation Value 2, kemudian berturut-turut diikuti kelas 1, 0, 3, 4 dst.

Tabel 4. Kriteria Kelas Loyalitas Pelanggan

\begin{tabular}{|r|l|l|}
\hline $\begin{array}{l}\text { RFM } \\
\text { Segmentation } \\
\text { Value }\end{array}$ & $\begin{array}{l}\text { Kelas } \\
\text { Pelanggan }\end{array}$ & Karakteristik \\
\hline 0 & Dormant & Mempunyai recency, frequency dan monetary terendah \\
\hline 1 & Ordinary & Pelanggan dengan loyalti cukup rendah \\
\hline 2 & & Pelanggan dengan loyalti sedang \\
\hline 4 & Golden & \\
\hline 5 & Superstar & Pelanggan dengan loyalti tinggi \\
\hline 6 & & \\
\hline
\end{tabular}

Tabel diatas menjelaskan pembagian kriteria kelas loyalitas pelanggan berdasarkan nilai dari variabel RFM Segmentation Value. Sehingga dapat diketahui berdasarkan Gambar 5, pelanggan terbanyak pada online retail tersebut adalah berkategori Ordinary yaitu dengan tingkat loyalty cukup rendah. Kemudian diikuti kategori Dormant, Golden dan Superstar. 


\section{KESIMPULAN}

CLV merupakan ukuran yang dapat digunakan untuk menentukan nilai seorang konsumen terhadap perusahaan secara kuantitatif. Nilai yang dihasilkan merupakan perhitungan keseluruhan yang dilakukan selama konsumen bertransaksi. Model RFM dapat digunakan untuk mendefinisikan seberapa berharganya konsumen bagi perusahaan. Semakin tinggi RFM Segmentation Value seorang konsumen, maka konsumen tersebut layak untuk di pertahankan. Oleh karena itu konsumen dengan kelas loyalitas tertinggi dapat di beri pelayanan optimal supaya konsumen tersebut tetap bertahan dan memberikan profit tertinggi kepada perusahaan. Metode segmentasi konsumen yang di bangun penulis dapat digunakan untuk optimasi strategi perusahaan untuk mendapat profit yang maksimum. Metode ini dapat diterapkan pada berbagai kasus dan perusahaan lain. Hasil penelitian ini diharapkan dapat membantu perusahaan untuk dapat bertahan di tengah krisis akibat Covid-19. Saran untuk penelitian selanjutnya perlu dilakukan pengembangan mengenai metode yang digunakan. Peningkatan metode segmentasi konsumen perlu dilakukan supaya mendapat hasil estimasi dan segmentasi yang tepat dan kuat.

\section{DAFTAR PUSTAKA}

1. Berger, Nasr (1998). Customer Lifetime Value: Marketing Models and application. Journal of Interaktive Marketing Volume 12, Number 1, Winter.

2. Borle, Sharad., Jain, Dipak C., Singh, Siddarth S (2008). Customer Lifetime Value Measurement. https://www.researchgate.net/publication/220534770

3. Casteran, Herbert., Reinartz, Werner., Meyer-Waarden, Lars (2017). Modelling Customer Lifetime Value, Retention and Churn. https://www.researchgate.net/publication/318167419

4. Gupta, S., Hanssens, D., Hardie, B., Kahn, W., Kumar, V., Lin, N., ... \& Sriram, S. (2006). Modeling customer lifetime value. Journal of service research, 9(2), 139-155.

5. Gupta S., Lehman D. R, Stuart J.A. (2004). Valuing Customers. Journal of Marketing Research.

6. Han, Jiawei., Kamber, Micheline., Pei, Jian. 2012. Data Mining Concept and Techniques. Waltham : Elsevier Inc

7. Holbrook, Morris B. 1999. Consumer Value: A Framework for Analysis and Research. London and New York : Routledge

8. Jasek, Pavel., Vrana, Lenka., Sperkova, Lucie., Smutny, Zdenek., Kobulsky, Marek (2018). Modeling and Application of Customer Lifetime Value in Online Retail.

9. Kumar V. (2007). Customer Lifetime Value: The Path to Profitability. Foundation \& Trends in Marketing, 2(1)

10. Kumar, V., \& Reinartz, W. (2006). Customer Relationship Management: A databased approach.

11. Reinartz, W. J., V. Kumar. 2003. The impact of customer relationshipcharacteristics on profitable lifetime duration. J. Marketing 6777-99. 